\title{
Restorative Justice and its impact on Primary Schools Students of Swat, KP- Pakistan: In Psychological Perspective
}

\author{
Maaz Ud Din', Worakamol Wisetsri², Faisal Khan ${ }^{3}$, Jutharat Pinthapataya ${ }^{4}$ \\ ${ }^{1} \mathrm{PhD}$ Scholar, Department of Management Sciences, University of Swabi, KP-Pakistan. \\ ${ }^{2}$ Worakamol Wisetsri, Associate Professor,Department of Manufacturing and Service Industry, Management , Faculty of Business \\ and Industrial Management, King Mongkut's University of Technology North Bangkok, Bangkok Thailand. \\ ${ }^{3}$ Faisal Khan, Assistant Professor Department of Management, University of Swabi, KP-Pakistan \\ ${ }^{4}$ Jutharat Pinthapataya, Department of Department of Industrial Business and Human Resource Development, Faculty of Business \\ and Industrial Management, King Mongkut's University of Technology North Bangkok,Bangkok, Thailand. , \\ ${ }^{1}$ maazyousafzai12@gmail.com, ${ }^{2}$ drkapook@gmail.com, ${ }^{3}$ faisalkhanutm@yahoo.com, ${ }^{4}$ jutharat.p@bid.kmutnb.ac.th
}

\begin{abstract}
Restorative justice is an alternative disciplinary approach to the traditional, punitive approach to discipline. The present study has done justice to the researcher'sexpectation to be a path breaking one in the region of Swat, KP-Pakistan for initiation Restorative justice, first as a class based intervention, and then to be offered after enrichment, a whole school programme.Despite its increasing recognition and use in Swat, Primary schools, a limited amount of research has evaluated the effect of restorative justice (RJ) for Primary schools and its impact, and response. To date, there is no standardized method for restorative justice implementation. The inherent qualities such as disciplining the students intrinsically, reducing the misconducts ranging from small cheating to causing wounds or loss to others, inducting students in peer mediation, and organizing Restorative justice mediation/conferencing for achieving reparation and restoration of relationships, and converting the entire institution as a place of social healing are shown to be a viability with Restorative justice. The present study enjoys the credit of successfully testing $78 \%$ of the Restorative justice practice in the primary schools. The reduction of misconducts in students and increase in their psychological capitals is a laudable performance of the Restorative justice in the maiden run for its approval and consideration.
\end{abstract}

Keywords

Restorative justice, Psychological capital, Peer mediation,Misconducts, Social healing

Article Received: 10 August 2020, Revised: 25 October 2020, Accepted: 18 November 2020

\section{Introduction}

Pakistan is democratic republic, where the people enjoy equality and rights in the domains of educational, social, legal,economical, moral and spiritual well-being.It is a known fact that equality in all aspects is possible, only when equality is achieved in the domain of education. The educational institutions need to cater to the needs of all learners coming from different sections of the society with clear differences in their emotional, intellectual, and social characteristics.Nelson, et al., (2020).

School is also a place where social problems are likely to emerge, cautioning the school administrators to adopt suitable measures linked to educational programs to act as a social healing process in educational institutions.School systems have traditionally used a prescriptive and, oftentimes, punitive framework to address misbehavior.As the school is a social arena, a miniature society functionalizing the aspirations of all the sub-cultural groups involved in receiving education, the school has the onerous responsibility of balancing the feelings of the students, be they offenders in wounding the feelings of the peer(s) or the victims of the harm done by the offenders Payne, \& Welch, (2018).The prevalence of misconduct among students is the source for separating students as victims and offenders. The offender meets with punishments, whether takes it seriously or not, he or she is sure to suffer because of the stigma glued to the name. In order to patch up the social and emotional cleavages occurred between the offenders and victims, the only remedy on hand is Restorative justice while victims on the other side suffer from hurt feelings and trauma due to loss of reputationOrtega, Lyubansky, Nettles, \&Espelage, D.L. (2016).

Education and literacy play a starring role in socioeconomic advancement and prosperity of a country. Primary education builds a strong foundation. In this regard, Education for All (EFA) is the main concern of the Government of Pakistan and it is (EFA) one of the primary tasks of the Government of Pakistan in the running decade (Ahmad Ali, 2019).

Restorative Justice has been traditionally defined through these concepts: (a) understanding that wrongs or harms result in obligations, (b), a focus on harm done and (c) the promotion of engagement and participation (Zehr, 2015). First, RJ views crime as harm done to people and communities. RJ emphasizes the relationships between individuals and their environment and the effects on these relationships when wrongdoings occur. The "social discipline window" (DeLanda, M. (2016), is a framework to simplify the relationship between these discipline practices.RJ provides the victims an opportunity to define their needs, on their own terms, as opposed to having their needs defined for them by an external system (e.g., traditional criminal justice system). Second, RJ recognizes that obligations result from harm that was caused while holding individuals accountable and responsible. Third, all primary parties affected by a conflict are provided with significant roles in the process of justice. Each party is identified as a "stakeholder" and plays a role in outlining how justice will be achieved. 
Mental health problems pose a significant challenge especially forthe students of Pakistan. Prior studies have suggested that prevalence of mental disorders,assault, victimization, bullying, and suicide among Pakistani students in comparison to other countries (Saleem, Mahmood, \&Naz, 2013; Bibi, Blackwell, \&Margraf, 2019), due to different challenging situations such asrelationship problems academic stress,financial issues,political turmoil and most important uncertain career goals. Several national organizations, such as the National Association of School Psychologists and the School Social Work Association of America, outline evidence-based practices and policies for improving school safety (Kingston et al., 2018).Among several kinds of psychological complications experienced by school students, one of the significant experiential challenge is social healing processin educational institutions.

Today's primary school students live in the age of Google, the age of technological and interpersonal transparency. Students will never have less information, be less connected, and conduct themselves less transparently than today. Achievement in the 21 st century will depend dramatically on one's ability to lead and "to thrive in a system of connections vaster, more varied, and more exposed than any time before in the history of man" (Reimer, K. E. 2019., p. 55). Applied behavior analysis focused on student curriculum contents, its modification, age of the students and skills learning level as well as the use of digital tools, modern technology and its proper use (Janet, 2018).

Education is the basic right for every human and a catalyst for, socioeconomic development and survival (World Bank, 1993). The educational institutions need to cater to the needs of all learners coming from different sections of the society with visible differences in their physical, intellectual, emotional and social characteristics. Education and culture play a starring role in physical, social and moral development of human beings. It is also a source of social existence as well Rubio, R. (2018). As the school is a social arena, a miniature society functionalizing the aspirations of all the sub-cultural groups involved in receiving education, the school has the onerous responsibility of balancing the feelings of the students, be they offenders in wounding the feelings of the peer(s) or the victims of the harm done by the offenders. When such small wounds caused by petty acts of fellow students are not attended in time, and healed, the accumulated ill feelings in tender hearts will be blown into unmanageable proportions quickly and threaten the entire society.

School is also a place where social problems are likely to emerge, cautioning the school administrators to adopt suitable measures linked to educational programmes to act as a social healing process 'in educational institutionsFaradova, G. (2020). The prevalence of misconduct 'among students is the source for separating students as offenders and victims. The victims suffer from hurt feelings and trauma due to loss of reputation.The offender on the other side meets with punishments, whether takes it seriously or not, he or she is sure to suffer because of the 'stigma' glued to the name. In order to patch up the social and emotional cleavages occurred between the offenders and victims, the only remedy on hand is Restorative justice.Pakistan has made great strides in adult education, but often encounters poverty, shortage of adequate food, ill-health and unsanitary conditions, lower or no income, inflation, joblessness, industrial sectors and animal grazing etc. All these out-of-school problems directly or indirectly related to the gigantic dropout Reimer, K. E. (2019).Each society passes the social heritage to the coming generation. An individual can achieve the multidimensional development of the soul and mind through education Kehoe, M., Bourke-Taylor, H., \& Broderick, D. (2018).

\section{Problem Statement}

Restorative justice had its introduction in criminal justice in different forms in different countries in different periods of time. Howard Zehr (1990), has noted in his Changing Lenses 'that the history of Restorative justice as it is known today began in the late 1970s when a group of Mennonites first suggested to a judge that victims and offenders in a series of vandalism cases be allowed to meet face-to-face to negotiate restitutionll. It marked the birth of restorative justice in the criminal justice framework. The fuller form of Restorative justice revolves around the theory that justice can prevent crime by making offenders feel more sympathy for their victims\| (Lawrence W. Sherman and Heather Strong, 2007). A wholesome and an easily understandable definition of Restorative justice states that Restorative justice is a process whereby all the parties with a stake in a particular offence come together to resolve collectively how to deal with the aftermath of the offence and its implications for the future (Marshall, 1999).

Thus the merit of Restorative justice is recognized in criminal justice process, with its adoption after a guilty plea, but before a sentencing decision. The crime and disorder act 1998 of UK (Lawrence W. Sherman and Heather Strong, 2007) has made it a major part of youth justice in the UK. The success of Restorative justice with in the areas of crime and criminal justice has pushed Restorative justice beyond the borders of crime, and placed it in school environments to resolve persistent problems of students with more formalized and comprehensive Restorative justice strategies. These Restorative justice approaches are highly helpful to address wide range of misconducts such as truancy, disciplinary, bullying, issues arising from disrespectful behaviors, conflicts, disputes, and petty crimes. This sort of Restorative justice programmes were introduced into Australian schools in the mid-1990s. Freire, P. (2018)followed by proactive/informal practices in everyday interactions between student and staff usually known as Restorative justice practice with or withoutfull blown Restorative justice conferencing. Taking all essential principles and modalities of Restorative justice the Researchers designed a Restorative justice intervention and introduced it in a school in 5th standard to systematically study the impact of Restorative justice on the psychological aspects of the student participants. The present research will serve as a pilot study for the Researchers to launch Restorative justice practices in the schools of Swat,Pakistan. 


\section{Experimental Process}

The Researchers worked out a detailed plan comprising a research design for launching a pilot study to implement a Restorative justice programme and study its effectiveness in reducing students 'misconducts and promoting their psychological capital. The process of experimentation proceeds as follows:

$\checkmark \quad$ An accommodative primary school are identified for introducing as Restorative justice practice.

$\checkmark$ Needed permission obtained from the school management.

$\checkmark$ Class 5th section $\mathrm{C}$ 'chosen as the Experimental group by lot.

$\checkmark$ Section A 'and B 'to serve as Control groups.

$\checkmark$ Class 5th C 'class teacher and other subject teachers are given enough inputs to practice Restorative justice.

$\checkmark$ Data sheets are distributed to the Experimental group teachers with necessary instructions.

$\checkmark$ Misconduct Checklist 'given with explanation for checking the occurrence of 4 categories of misconducts and filling data sheets.

$\checkmark$ Model master table given to teachers for consolidated data entry

$\checkmark \quad$ In case of severe harm to victim, mediation is planned and the process of execution is well structured

$\checkmark$ After a lapse of 20 days from the date of introduction, peer mediation was added in the Restorative justice process for strengthening the practices.

$\checkmark \quad$ A Rating scale for assessing the Psychological capital will be given to teachers for rating Hope, Efficacy, Resilience and Optimism.

$\checkmark$ At the end of every week data sheets are to be completed and given to Researchers for verification.

$\checkmark$ At the end of every month, master table is to be completed and handed over to Researchers.

$\checkmark \quad$ The Research Supervisor as the Restorative justice director, the Research scholar as the Restorative justice coordinator, often meet Restorative justice practitioners (teachers) including Student practitioners (peer mediators) and appraise the genuineness of the work and boost their motivation.

$\checkmark \quad$ Altogether the Restorative justice programme lasts for 4 months.

$\checkmark$ The time-series research design is followed.

$\checkmark \quad$ Of the 4 sets of data, each set is compared with the successive one to find the progressing, or falling or (unchanging) condition/status of the Experimental effect over the psychologicalaspects of the students.

$\checkmark$ Comparison with the control groups will also yield information about the effectiveness of the intervention.

\section{Need And Significance}

Time and again, the social and print media report about occurrences of problems among school and college students ruining not only their academic performance but also the harmony among different communities. Therefore, the institutions are in need of a fool proof strategy to amicably settle the conflicts arising among peers. The mediation process of Restorative justice, is a valid one for securing social healing 'in the social arena of educational institutions. Therefore, a study on the effectiveness of Restorative justice in school context is a much needed one. A survey done by the researchers has confirmed a large scale prevalence of misconducts, that too in the category of overt aggression followed by covert disruptive behavior. Furthermore, the disciple process followed in schools are predominantly informal 'in nature without a definite structure or a role to play. The least adopted one is the creative / innovative strategy to correct problems in students. In this category also, the strategies adopted are not genuinely innovative or creative and properly systematized. Therefore, the present study is a much needed one to find the hurdles in the adoption of Restorative justice in schools.

\section{Population And Sample}

All the students studying from standard 4th to 5th in the schools in Swat district form the population of the study. The sample of the Experimental group is formed of 45 students in standard 5th $\mathrm{C}$ 'in the chosen Primary school in Swat district. Moreover, in the same school, the students in 5th A 'and5th B 'are chosen as sample (2) and (3) serving as comparison groups

\section{Method}

The stated problem demands Experimental form of research with time-series research design.

\section{Objectives}

1) To find the significance of difference between the pretest scores and posttest 1 scores, posttest 1 and posttest 2 scores, posttest 2 and posttest 3 scores obtained on the intensity of misconducts in the chosen experimental group.

2) To find the significance of difference between the pretest scores and posttest 1 scores, posttest 1 and posttest 2 scores, posttest 2 and posttest 3 scores obtained on the psychological capitals of the experimental groups.

3) To find the significance of relationship between the intensity of misconducts and the psychological capitals of the experimental group.

4) To find the significance of predictability of psychological capitals over the intensity of misconducts of the experimental group. 


\section{Research Tools}

- Misconduct Checklist-Prepared by the Researchers.

- Psychological Capital Rating scale - Prepared by the Researcher.

\section{Initiation And Data Collection}

After fixing school, standard and sections, and the teachers teaching different school subjects to the chosen class, the Researchers convened a meeting with the five subject masters of the class, of which one was the class teacher, shouldering the responsibility of Restorative justice in charge of the class. In the first formal meeting they were given a clear exposition about the need, process, and execution of Restorative justice with necessary data sheets, data collecting instruments - Misconducts checklist and Psychological capitals rating scale, procedure for recording data for 5 days a week and then to be transferred to data sheet, etc. The very next day after the meeting, the 5 teachers started practicing Restorative justice and the pretest was conducted within a week. At the end of 4 weeks using the recorded data in the 4 data sheets, given by each one of the Restorative justice practicing teachers, the Restorative justice in-charge of the class consolidated and prepared the master table. In the first month, the Research supervisor in the capacity of Restorative justice coordinator of the school, and the Research supervisor in the capacity of Restorative justice director of the school visited once in 10 days and interacted with the Restorative justice practitioners informally and appraised the quality of the process of execution. During the third meeting with Restorative justice practitioners, the Restorative justice director and Restorative justice coordinator in consultation with them formed a peer mediation group 'comprising 3 students of exemplary character with very good track record of academic achievement, and trained them how to be helpful to teachers to execute Restorative justice practice. Hence the Restorative justice project team was able to develop 4 master tables providing data about occurrence / intensity of misconducts under 4 categories, scores for psychological capitals assessed, situational details of the misdeeds occurred, offenders 'andvictims 'on the spot reactions, and their family backgrounds. Thus after initiation the data needed for testing the effectiveness of Restorative justice were collected. Due to paucity of time, the Researchers were not able to generate data from the comparison groups $\mathrm{A}$ and $\mathrm{B}$, and as such the concerned statistical analysis was dropped.

\section{Data Analysis}

Hypothesis -1 There is no significant difference between the mean scores of the pretest and posttest 1 scores obtained on misconducts of primary school students of Experimental group.
Table 1 Difference between the mean scores of the pretest and posttest 1 scores obtained on misconducts of primary school students of experimental group

\begin{tabular}{|l|l|c|l|l|l|l|l|}
\hline Variable & Group & $\mathrm{N}$ & Mean & S.D & r-value & t-value & P-value \\
\hline $\begin{array}{l}\text { Overt } \\
\text { Aggressive } \\
\text { Behavior }\end{array}$ & Pre test & 45 & 33.5 & 1.94 & 0.29 & 3.05 & $0.00^{* *}$ \\
\cline { 2 - 8 } & Post test 1 & 45 & 32.2 & 1.78 & & & \\
\hline $\begin{array}{l}\text { Covert } \\
\text { Disnuptive } \\
\text { Behavior }\end{array}$ & Pre test & 45 & 24.1 & 1.66 & 0.25 & 2.21 & $0.03^{*}$ \\
\cline { 2 - 8 } & Post test 1 & 45 & 23.3 & 1.57 & & & \\
\hline $\begin{array}{l}\text { Attention } \\
\text { Problems }\end{array}$ & Pre test & 45 & 20.1 & 1.44 & 0.24 & 2.15 & $0.003^{*}$ \\
\cline { 2 - 8 } & Post test 1 & 45 & 19.7 & 1.41 & & & \\
\hline $\begin{array}{l}\text { Emotional } \\
\text { Opposition } \\
\text { Behavior }\end{array}$ & Pre test & 45 & 14.5 & 1.04 & 0.28 & 2.43 & $0.02^{*}$ \\
\cline { 2 - 8 } & Post test 1 & 45 & 13.6 & 1.04 & & & \\
\hline $\begin{array}{l}\text { Overall } \\
\text { Misconducts }\end{array}$ & Pre test & 45 & 87.2 & 3.46 & 0.32 & 4.24 & $0.00^{* *}$ \\
\cline { 2 - 8 } & Post test 1 & 45 & 86.1 & 3.46 & & & \\
\hline
\end{tabular}

$* *$ significant at $1 \%$ level
$* *$ significant at $5 \%$ level

Hypothesis - 2 There is no significant difference between the mean scores of the posttest 1 and posttest 2 obtained on misconducts of primary school students of Experimental group.

Table - II Difference between the mean scores of the posttest 1 and posttest 2 obtained on misconducts of primary school students of Experimental group

\begin{tabular}{|l|l|c|l|l|l|l|l|}
\hline Variable & Group & $\mathrm{N}$ & Mean & S.D & r-value & t-value & P-value \\
\hline $\begin{array}{l}\text { Overt } \\
\text { Aggressive } \\
\text { Behavior }\end{array}$ & Pre test & 45 & 32.5 & 1.74 & 0.30 & 4.55 & $0.00^{* *}$ \\
\cline { 2 - 8 } & Post test 1 & 45 & 38.2 & 1.68 & & & \\
\hline $\begin{array}{l}\text { Covert } \\
\begin{array}{l}\text { Disnuptive } \\
\text { Behavior }\end{array}\end{array}$ & Pre test & 45 & 23.1 & 1.56 & 0.35 & 3.21 & $0.00^{* * *}$ \\
\cline { 2 - 8 } & Post test 1 & 45 & 22.3 & 1.50 & & & \\
\hline $\begin{array}{l}\text { Attention } \\
\text { Problems }\end{array}$ & Pre test & 45 & 19.1 & 1.43 & 0.28 & 4.05 & $0.00^{* * *}$ \\
\cline { 2 - 8 } & Post test 1 & 45 & 17.31 & 1.35 & & & \\
\hline $\begin{array}{l}\text { Emotional } \\
\text { Opposition } \\
\text { Behavior }\end{array}$ & Pre test & 45 & 12.86 & 1.02 & 0.36 & 7.33 & $0.00^{* * *}$ \\
\cline { 2 - 8 } & Post test 1 & 45 & 12.14 & 0.93 & & & \\
\hline $\begin{array}{l}\text { Overall } \\
\text { Misconducts }\end{array}$ & Pre test & 45 & 86.2 & 3.36 & 0.34 & 6.84 & 0.00 \\
\cline { 2 - 8 } & Post test 1 & 45 & 86.1 & 3.46 & & & \\
\hline
\end{tabular}

** significant at $1 \%$ level

Hypothesis - 3 There is no significant difference between the mean scores of posttest 2 and posttest 3 obtained on misconducts of primary school students of Experimental group. 
Table - III Difference between the mean scores of posttest 2 and posttest 3 obtained on misconducts of primary school students of Experimental group

\begin{tabular}{|l|l|c|l|l|l|l|l|}
\hline Variable & Group & $\mathrm{N}$ & Mean & S.D & r-value & t-value & P-value \\
\hline \multirow{2}{*}{ Hope } & Pre test & 45 & 3.65 & 0.94 & 0.24 & 2.35 & $0.02^{*}$ \\
\cline { 2 - 8 } & Post test 1 & 45 & 5.01 & .98 & & & \\
\hline Efficacy & Pre test & 45 & 2.91 & 0.91 & 0.19 & 1.84 & 0.06 \\
\cline { 2 - 9 } & Post test 1 & 45 & 32.3 & 0.92 & & & \\
\hline \multirow{2}{*}{ Optimism } & Pre test & 45 & 3.14 & 0.83 & 0.18 & 2.39 & $0.02^{*}$ \\
\cline { 2 - 8 } & Post test 1 & 45 & 3.52 & 0.91 & & & \\
\hline Resilience & Pre test & 45 & 3.46 & 0.62 & 0.21 & 2.37 & $0.03^{*}$ \\
\cline { 2 - 8 } & Post test 1 & 45 & 4.02 & 3.43 & & & \\
\hline
\end{tabular}

Hypothesis -4 There is no significant difference between the mean scores of pretest and the mean posttest 1 scores obtained on psychological capitals of primary school students of Experimental group.

Table - IV Difference between the mean scores of pretest and posttest 1 scores obtained on psychological capitals of primary school students of Experimental group

\begin{tabular}{|l|l|c|l|l|l|l|l|}
\hline Variable & Group & $\mathrm{N}$ & Mean & S.D & r-value & t-value & P-value \\
\hline $\begin{array}{l}\text { Overt } \\
\text { Aggressive } \\
\text { Behavior }\end{array}$ & Post test 2 & 45 & 29.5 & 1.64 & 0.36 & 18.95 & $0.00^{* *}$ \\
\cline { 2 - 8 } & Post test 3 & 45 & 18.52 & 1.43 & & & \\
\hline $\begin{array}{l}\text { Attention } \\
\text { Problems }\end{array}$ & Post test 2 & 45 & 17.43 & 1.35 & 0.35 & 5.91 & $0.00^{* *}$ \\
\cline { 2 - 8 } & Post test 3 & 45 & 15.65 & 1.31 & & & \\
\hline \multirow{2}{*}{$\begin{array}{l}\text { Emotional } \\
\text { Opposition } \\
\text { Behavior }\end{array}$} & Post test 2 & 45 & 11.46 & 0.94 & 0.36 & 8.17 & $0.00^{* *}$ \\
\cline { 2 - 8 } & Post test 3 & 45 & 9.67 & 0.91 & & & \\
\hline $\begin{array}{l}\text { Overall } \\
\text { Misconducts }\end{array}$ & Post test 2 & 45 & 79.34 & 3.86 & 0.46 & 17.14 & $0.00^{* *}$ \\
\cline { 2 - 8 } & Post test 3 & 45 & 66.1 & 3.26 & & & \\
\hline
\end{tabular}

Hypothesis -5 There is no significant difference between the mean scores of posttest 1 and mean scores of posttest 2 obtained on psychological capitals of primary school students of Experimental group.

Table $-\mathbf{V}$ Difference between the mean scores of posttest 1 and mean scores of posttest 2 obtained on psychological capital of primary school students of Experimental group

\begin{tabular}{|l|l|c|l|l|l|l|l|}
\hline Variable & Group & $\mathrm{N}$ & Mean & $\mathrm{S} . \mathrm{D}$ & $\mathrm{r}$-value & $\mathrm{t}$-value & P-value \\
\hline Hope & Pre test 1 & 45 & 4.05 & 0.98 & 0.24 & 4.02 & $0.00^{* *}$ \\
\cline { 2 - 8 } & Post test 2 & 45 & 4.94 & 1.02 & & & \\
\hline \multirow{2}{*}{ Efficacy } & Post test 1 & 45 & 3.31 & 0.96 & 0.27 & 5.19 & $0.00^{* *}$ \\
\cline { 2 - 8 } & Post test 2 & 45 & 4.43 & 1.02 & & & \\
\hline \multirow{3}{*}{ Optimism } & Pre test & 45 & 3.14 & 0.83 & 0.18 & 2.39 & $0.02^{*}$ \\
\cline { 2 - 8 } & Post test 1 & 45 & 3.52 & 0.91 & & & \\
\hline Resilience & Pre test & 45 & 3.46 & 0.62 & 0.21 & 2.37 & $0.03^{*}$ \\
\cline { 2 - 8 } & Post test 1 & 45 & 4.02 & 3.43 & & & \\
\hline
\end{tabular}

Hypothesis -6 There is no significant difference between the mean scores of posttest 2 and mean scores of posttest 3 obtained on psychological capitals of primary school students of Experimental group.

\begin{tabular}{|l|l|c|l|l|l|l|l|}
\hline Variable & Group & $\mathrm{N}$ & Mean & S.D & r-value & t-value & P-value \\
\hline Hope & Post test 2 & 45 & 4.95 & 1.03 & 0.27 & 5.24 & $0.00^{* *}$ \\
\cline { 2 - 8 } & Post test 3 & 45 & 6.14 & 1.05 & & & \\
\hline Efficacy & Post test 2 & 45 & 4.47 & 1.02 & 0.23 & 6.40 & $0.00^{* *}$ \\
\cline { 2 - 8 } & Post test 3 & 45 & 5.98 & 1.04 & & & \\
\hline \multirow{2}{*}{ Optimism } & Pre test 2 & 45 & 4.49 & 0.96 & 0.28 & 6.39 & $0.00^{* *}$ \\
\cline { 2 - 9 } & Post test 3 & 45 & 6.01 & 1.03 & & & \\
\hline Resilience & Post test 2 & 45 & 5.21 & 0.82 & 0.28 & 8.17 & $0.00^{* *}$ \\
\cline { 2 - 8 } & Post test 3 & 45 & 4.02 & 3.43 & & & \\
\hline
\end{tabular}

Hypothesis -7 There is no significant relationship between the intensity of misconducts and the psychological capitals of primary school students of the Experimental group.

\begin{tabular}{|c|c|c|c|c|}
\hline Variable & Group & $\mathrm{N}$ & $\begin{array}{l}\text { Calculated ' } \mathrm{r} \text { ' } \\
\text { Value }\end{array}$ & $\mathrm{P}$ value \\
\hline \multirow{4}{*}{$\begin{array}{l}\text { Overt } \\
\text { Aggressive } \\
\text { Behavior }\end{array}$} & Hope & 45 & -0.28 & 0.12 \\
\hline & Efficacy & 45 & -.018 & 0.18 \\
\hline & Optimism & 45 & -0.35 & $0.03 *$ \\
\hline & Resilience & 45 & -0.24 & 0.16 \\
\hline \multirow{4}{*}{$\begin{array}{l}\text { Covert } \\
\text { Disruptive } \\
\text { behavior }\end{array}$} & Hope & 45 & -0.45 & $0.00 * *$ \\
\hline & Efficacy & 45 & -0.29 & 0.08 \\
\hline & Optimism & 45 & -.0 .25 & 0.14 \\
\hline & Resilience & 45 & -0.47 & $0.00 * *$ \\
\hline \multirow{4}{*}{$\begin{array}{l}\text { Attention } \\
\text { behavior }\end{array}$} & Hope & 45 & -0.31 & 0.06 \\
\hline & Efficacy & 45 & -0.32 & $0.04 *$ \\
\hline & Optimism & 45 & -0.24 & 0.13 \\
\hline & Resilience & 45 & -0.33 & $0.04 *$ \\
\hline \multirow{4}{*}{$\begin{array}{l}\text { Emotional } \\
\text { Opposition } \\
\text { Behavior }\end{array}$} & Hope & 45 & -0.44 & $0.00 *$ \\
\hline & Efficacy & 45 & -0.42 & $0.00 * *$ \\
\hline & Optimism & 45 & -0.31 & $0.04 *$ \\
\hline & Resilience & 45 & -0.23 & 0.13 \\
\hline \multirow{4}{*}{$\begin{array}{l}\text { Overall } \\
\text { Misconducts }\end{array}$} & Hope & 45 & -0.34 & $0.03 *$ \\
\hline & Efficacy & 45 & -0.38 & $0.02 *$ \\
\hline & Optimism & 45 & -0.45 & $0.00 * *$ \\
\hline & Resilience & 45 & -0.47 & $0.00 * *$ \\
\hline
\end{tabular}


Hypothesis - 8 Psychological capitals are not significant enough to predict the intensity of misconducts among the primary school students of Experimental group.

Table - VIII Nature of prediction of psychological capitals over intensity of misconducts among primary school students of Experimental group.

\begin{tabular}{|c|c|c|c|c|c|}
\hline $\begin{array}{l}\text { Dependent } \\
\text { Variable }\end{array}$ & Equation & $\mathrm{R}^{2}$ & Variables & $\begin{array}{l}\text { Calculated } \\
\text { 'r' Value }\end{array}$ & P value \\
\hline \multirow{4}{*}{$\begin{array}{l}\text { Overt } \\
\text { Aggressive } \\
\text { Behavior }\end{array}$} & \multirow{4}{*}{$\begin{array}{l}13.19+ \\
(0.04 * \mathrm{HO}) \\
+(0.07 * \mathrm{EF}) \\
+(0.09 * \mathrm{OP}) \\
+(0.05 * \mathrm{RE})\end{array}$} & \multirow{4}{*}{0.08} & Hope & -0.28 & 0.12 \\
\hline & & & Efficacy & -0.17 & 0.18 \\
\hline & & & Optimism & -0.37 & $0.03^{*}$ \\
\hline & & & Resilience & -0.26 & 0.16 \\
\hline \multirow{4}{*}{$\begin{array}{l}\text { Covert } \\
\text { Disruptive } \\
\text { behavior }\end{array}$} & \multirow{4}{*}{$\begin{array}{l}18.54+ \\
(0.04 * \mathrm{HO}) \\
+(0.03 * \mathrm{EF}) \\
+(0.06 * \mathrm{OP}) \\
+(0.11 * \mathrm{RE})\end{array}$} & \multirow[t]{4}{*}{0.06} & Hope & -0.44 & $0.00 * *$ \\
\hline & & & Efficacy & -0.27 & 0.07 \\
\hline & & & Optimism & -0.26 & 0.14 \\
\hline & & & Resilience & -.046 & $0.00 * *$ \\
\hline \multirow{4}{*}{$\begin{array}{l}\text { Attention } \\
\text { behavior }\end{array}$} & \multirow{4}{*}{$\begin{array}{l}17.62+ \\
(0.05 * \mathrm{HO}) \\
+\left(0.08^{*} \mathrm{EF}\right) \\
+(0.06 * \mathrm{OP}) \\
+\left(0.09^{*} \mathrm{RE}\right)\end{array}$} & \multirow[t]{4}{*}{0.09} & Hope & -0.31 & 0.06 \\
\hline & & & Efficacy & -0.32 & $0.04 *$ \\
\hline & & & Optimism & -0.24 & 0.13 \\
\hline & & & Resilience & -0.34 & $0.04^{*}$ \\
\hline \multirow{4}{*}{$\begin{array}{l}\text { Emotional } \\
\text { Opposition } \\
\text { Behavior }\end{array}$} & \multirow{4}{*}{$\begin{array}{l}10.51+ \\
(0.07 * \mathrm{HO}) \\
+(0.09 * \mathrm{EF}) \\
+(0.11 * \mathrm{OP}) \\
+(0.04 * \mathrm{RE})\end{array}$} & \multirow[t]{4}{*}{0.04} & Hope & -0.45 & $0.00^{*}$ \\
\hline & & & Efficacy & -0.42 & $0.00 * *$ \\
\hline & & & Optimism & -0.31 & $0.04^{*}$ \\
\hline & & & Resilience & -0.23 & 0.13 \\
\hline \multirow{4}{*}{$\begin{array}{l}\text { Overall } \\
\text { Misconducts }\end{array}$} & \multirow{4}{*}{\begin{tabular}{|l|}
$26.54+$ \\
$(0.21 * \mathrm{HO})$ \\
$+(0.14 * \mathrm{EF})$ \\
$+(0.28 * \mathrm{OP})$ \\
$+(0.21 * \mathrm{RE})$
\end{tabular}} & \multirow[t]{4}{*}{0.15} & Hope & -0.35 & $0.03^{*}$ \\
\hline & & & Efficacy & -0.39 & $0.02 *$ \\
\hline & & & optimism & -0.46 & $0.00 * *$ \\
\hline & & & Resilience & -0.47 & $0.00 * *$ \\
\hline
\end{tabular}

\section{Findings Of The Study}

The followings are the findings deduced from statistical analysis of the data:

- On testing the significance of difference between pretest, and posttest 1 in the intensity of misconducts among the primary school students of Experimental group, it is found that the misconducts score in the posttest 1 was significantly lesser than the pretest score before the commencement of the intervention programme.

- Significant difference was observed between the posttest 1 and posttest 2 in the occurrence of misconducts among the primary school students of Experimental group. Posttest 2, after the intervention 2 depicted a significant decline from the score obtained in posttest 1 .

- Testing the significance of difference between the posttest 2 and posttest 3 in the intensity of misconducts, it was found that there was a significant decrease in the intensity of misconducts score from posttest 2 to posttest 3 .

- On testing the significance of difference between pretest and posttest 1 in the psychological capitals among the primary school students of Experimental group, it is found that the psychological capitals score in the posttest 1 was significantly higher than their pretest score before the commencement of the intervention programme.

- Significant difference was observed between the posttest 1 and posttest 2 of the psychological capitals scores among the primary school students of Experimental group. Posttest 2 after the intervention showed a significant increase from the scores obtained on posttest 1 .

- Testing the significance of difference between the posttest 2 and posttest 3 scores of psychological capitals, it is found that there was a significant increase in the psychological capital score from posttest 2 to posttest 3 .

- While testing the significance of relationship between the intensity of misconducts and psychological capitals of primary school students of Experimental group after the intervention, it is found that there was significant negative relationship between the intensity of overall misconducts and the psychological capitals - Hope, Efficacy, Optimism and Resilience. In the dimension wise computation, it isfound that Overt aggressive behavior was negatively related only with optimism; the Covert disruptive behavior negatively related with Hop and Resilience; Attention problem with Efficacy and Resilience; and Emotional opposition behavior with Hope, Efficacy and Optimism.

- The computed multiple regression analysis reveals that overall Misconducts was significantly predicted by all the four psychological capitals - Hope, Efficacy, Optimism and Resilience. However, the dimension wise analysis shows that Overt aggressive behavior was significantly predicted by Optimism and Efficacy; Covert disruptive behavior was by Hope, Optimism and Resilience; Attention problems by Efficacy and Resilience; and Emotional opposition behavior by Hope, Efficacy and Optimism.

\section{Discussion And Conclusion}

Following time-series research design, the decrease in the occurrence / intensity of misconducts in class 5th students due to the ongoing intervention process of Restorative justice practices was tested by $\mathrm{t}$ 'test in three phases with one-month interval in between among them. All the three phases of testing confirmed the reduction in the occurrence / intensity of misconducts due to Restorative justiceintervention. However, one could note the level of significance differing to confirm the decline in the occurrence / intensity of misconducts in phase 1 from that of phase 2 and phase 3 . In phase 1 the decrease in misconducts is confirmed by 0.01 level of significance for overall misconducts and its dimension Overt aggressive behavior; whereas in the case of other three dimensions, the confirmation is only at 0.05 level of significance. The researchers attribute this variation to the effect of peer mediation 'introduced somewhere in the middle of the first phase to support and supplement the Restorative justice 
works of teachers. As the impact of peer mediation started influencing the reduction process of misconducts towards the end of phase 1, in other two phases 2 and 3 the reduction of misconducts is confirmed at 0.01 level of significance for overall misconducts and all its four dimensions. It is overwhelmingly confirmed in the case of psychological capitals also. In phase 1 , out of 4 psychological capitals Efficacy is not increased significantly in spite of intervention. In the case of other three also Hope, Optimism and Resilience - the increase is confirmed only at 0.05 level of significance. It may be due to the nature of these psychological capitals requiring long term intervention for sizable development in them. Or else it may be attributed to the delayed introduction of peer mediation during the first phase of intervention. Nevertheless, the recorded significant development in Hope, Efficacy, Optimism and Resilience in the following two phases 2 and 3 confirmed at 0.01 level of significance, seems to uphold both the assumptions. The correlation analysis confirms the significance of relationship between overall misconducts and psychological capitals Optimism and Resilience at 0.01 level, while Hope and Efficacy at 0.05 level revealing the difference in the strength of relationship among the four capital factors, with Optimism and Resilience tied up more closely but negatively with overall misconducts. Somewhat similar behavior is found between capital factors and dimensions of misconducts which the researchers attribute to the nature of misconducts. Moreover, the long range confirmation of psychological capitals 'contribution to minimize overall misconducts is evident from the outcomes of prediction analysis. The noted difference in the predictability of 4 capital factors over the dimensions of misconducts is attributed to the characteristic feature of the dimensions. Thus, the study confirms the feasibility of the application of RJ in schools, and its utility in uprooting unwanted negative behaviors and for planting the positive ones.

\section{References}

[1] Acosta, J., Chinman, M., Ebener, P., Malone, P. S., Phillips, A., \& Wilks, A. (2019). Evaluation of a whole-school change intervention: Findings from a twoyear cluster-randomized trial of the restorative practices intervention. Journal of Youth and Adolescence, 48(5), 876890. https://doi.org/10.1007/s10964-01901013-2.

[2] DeLanda, M. (2016). Assemblage theory. Edinburgh, UK: Edinburgh University Press.

[3] Evans, K., \&Vaandering, D. (2016). The little book of restorative justice in education: Fostering responsibility, healing, and hope in schools. Skyhorse Publishing, Inc.
[4] Evans, K., \&Vaandering, D. (2016). The little book of restorative justice in education: Fostering responsibility, healing, and hope in schools. Skyhorse Publishing, Inc.

[5] Freire, P. (2018). Pedagogy of the oppressed (4th ed.). New York, NY: Bloomsbury Academic.

[6] Faradova, G. (2020). Adult Education: Contribution to the Sustainable Development Goals. Quality Education, 117.

[7] Janet Twymana, William L. Hewardb, 2018, How to improve student learning in every classroom now Janet S. International Journal of Educational Research 87,78-90.

[8] Kehoe, M., Bourke-Taylor, H., \& Broderick, D. (2018). Developing student social skills using restorative practices: A new framework called HEART. Social Psychology of Education, 21(1), 189-207. https://doi.org/10.1007/s11218-017-94021.

[9] Kehoe, M., Bourke-Taylor, H., \& Broderick, D. (2018). Developing student social skills using restorative practices: A new framework called HEART. Social Psychology of Education, 21(1), 189-207. https://doi.org/10.1007/s11218-017-94021.

[10] Nelson, Jack L., Stuart B. Palonsky, and Mary Rose McCarthy 2020. Critical issues in education. Waveland Press,.

[11] Ortega, L., Lyubansky, M., Nettles, S., \&Espelage, D.L. (2016). Outcomes of a restorative circles program in a high school setting. Psychology of Violence, 6, 459-468. doi:10.1037/vio0000048.

[12] Payne, A. A., \& Welch, K. (2018). The effect of school conditions on the use of restorative justice in schools. Youth Violence and Juvenile Justice, 16, 224240. doi:10.1177/1541204016681414

[13] Reimer, K. E. (2019). Relationships of control and relationships of engagement: How educator intentions intersect with student experiences of restorative justice. Journal of Peace Education, 16(1), 49-77. 
https://doi.org/10.1080/17400201.

2018.1472070 .

[14]

[15] Rubio, R. (2018). Effective implementation practices of restorative justice: A qualitative case study [Doctoral dissertation]. University of La Verne.

[16] Reimer, K. E. (2019). Relationships of control and relationships of engagement: How educator intentions intersect with student experiences of restorative justice. Journal of Peace Education, 16(1), 49-77. https://doi.org/10.1080/17400201. 2018.1472070.

[17] Reimer, K. E. (2019). Relationships of control and relationships of engagement: How educator intentions intersect with student experiences of restorative justice. Journal of Peace Education, 16(1), 49-77. https://doi.org/10.1080/17400201. 2018.1472070.

[18] Rubio, R. (2018). Effective implementation practices of restorative justice: A qualitative case study [Doctoral dissertation]. University of La Verne.

[19] Reimer, K. E. (2019). Relationships of control and relationships of engagement: How educator intentions intersect with student experiences of restorative justice. Journal of Peace Education, 16(1), 49-77. https://doi.org/10.1080/17400201.

2018.1472070. 